\title{
Corporate Social Bonds: A Legal Analysis
}

by

\author{
DileTtA LenZi*
}

The article focuses on corporate social bonds, which are commonly defined as debt securities whose proceeds are used to finance projects or ventures at favourable conditions, in order to achieve positive social outcomes or to address specific social issues. Social bonds belong to the family of sustainable finance currently developing on international financial markets, especially in the European Union, and where a recent interest has also emerged at the political level. Although in March 2018 the European Commission published its Action Plan on Financing Sustainable Growth, at the moment of writing there is no specific EU legal framework for social bonds. The absence of a precise definition of social bonds and the uncertainty around the remedies for non-compliance of promised 'social' obligations entail serious risks of 'socialwashing' (i.e., the misappropriation of an increasingly attractive label). Through an analysis of the contractual design of social bonds, and the identification of different types of social bonds, the article identifies potential legal 'Achilles heels' of social bonds and suggests possible contractual remedies to ensure that both issuers and beneficiaries comply with their duties in terms of social impact achievement. Finally, the article suggests a European Union intervention in developing a 'goal-oriented' definition for social bonds.

Table of Contents

ECFR 2021, 291-319

1. Introduction $\ldots \ldots \ldots \ldots \ldots \ldots \ldots \ldots \ldots \ldots \ldots \ldots$

1.1. The European Legal Framework for Sustainable Finance and the International Market of Socially Responsible Investments . . . . . . . . . . . 292

1.2. Social Impact Investing . . . . . . . . . . . . . . . . . . . . . . . . 294

2. Social Bonds: Towards a Common Definition . . . . . . . . . . . . . . . . 296

3. Core Characteristics of Social Bonds . . . . . . . . . . . . . . . . . . . 299

3.1. The Issuers of Social Bonds and Their Role in Achieving the Social Impact 300

* Post-Doc Research Fellow at the University of Florence - Faculty of Law (Italy).

Note: The Article has benefitted from the author's participation in the research project 'From the theory of social finance to a concrete social bond' directed by Riccardo Salomone, held at the University of Trento-Faculty of Law and financed by Fondazione CARITRO (March 2018-March 2020). A preliminary version of this Article was presented at the workshop 'Finance for sustainability', organised by Beate Sjafjell within the 'Daughters of Themis Network' (June 2019), when the paper has received beneficial remarks. The author would like to thank Lorenzo Stanghellini, Andrea Zorzi and Luigi Vigoriti for their valuable advice and precious comments on the final version of the paper. The usual disclaimers apply.

2 Open Access. (C) 2021 Diletta Lenzi, published by De Gruyter. (c) BY This work is licensed under the Creative Commons Attribution 4.0 International License. 
3.2. The 'Social' Side of Social Bonds: The Lack of a Common Definition of 'Social Impact' . . . . . . . . . . . . . . . . . . . . . . . . . . . . . . . . . . . . . 301

3.3. Bondholder Remuneration . . . . . . . . . . . . . . . . . 303

4. The Integrity of the Social Bond Market: How to Reduce 'Socialwashing' . . 304

4.1. Allocating Proceeds for the Social Impact . . . . . . . . . . . . . . 306

4.2. Bondholder Ability to Monitor the Generation of the Social Impact . . . 307

4.2.1. The Importance of Clearly Identifying the Social Impact . . . . . . . 307

4.2.2. Ex Ante and On-Going Disclosure of Information . . . . . . . . 308

4.3. Making Monitoring and Enforcement Effective . . . . . . . . . . . 311

4.4. Consequences of Non-Fulfilment of the 'Social' Obligation . . . . . . . 312

5. Review Provider . . . . . . . . . . . . . . . . . . . . . . . 315

6. Final Remarks. A Goal-Oriented 'Label' for Social Bonds? . . . . . . . . . . 315

\section{Introduction}

\subsection{The European Legal Framework for Sustainable Finance and the International Market of Socially Responsible Investments}

Expressions such as 'sustainable finance' or 'socially responsible investment' (SRI) usually refer to investors financing projects and ventures in order to generate a positive impact for society and/or the environment. Empirical studies of the European market show that institutional investors (mainly pension funds and insurers) increasingly invest in organisations, enterprises and projects that have a positive social and environmental impact, and in recent years we have witnessed the emergence of several forms of social financing. ${ }^{1}$

1 The 2018 Eurosif study provides an overview of the SRI market in 2016 and 2017. The study covers 13 European markets, and includes professionally managed SRI assets that are subject to one or more of the so-called 'SRI strategies'. In total, 263 asset managers and asset owners participated in the survey (with combined assets under management of Euro 20 trillion, covering approximately $79 \%$ of the SRI market). The Eurosif Report shows rapid growth in the SRI market: the overall percentage of retail investors interested in the European SRI industry, for instance, grew from 3.4\% in 2013 to $31 \%$ in 2017. The report is available on the Eurosif website (www.eurosif.org).

However, reports on the SRI market have been criticised for being weak when it comes to defining what actually constitutes a 'socially responsible investment', and of ignoring the actual extent and quality of such practices. If a more restrictive definition of socially responsible investments applies, the SRI market is likely to be smaller than the surveys suggest. See Benjamin J. Richardson, "Keeping Ethical Investment Ethical: Regulatory Issues for Investing for Sustainability”, Journal of Business Ethics, 2009, 87, 555. Another weakness is revealed by the Report, where it states that "As data collection is primarily based on our SRI market participant survey, one important limitation of the Study re- 
At the European Union level, 'sustainable finance' is commonly defined as that segment of the financial industry characterised by (i) the goal of financing sustainable and inclusive growth in the real economy and (ii) the incorporation of $\mathrm{ESG}^{2}$ factors in investors' decision-making process. ${ }^{3}$

Particularly, the European Commission considers private finance as a necessary driver towards more sustainable growth since, to this end, "the scale of the investment challenge is beyond the capacity of the public sector alone"; ${ }^{4}$ and it is strongly engaged in promoting sustainable finance. In 2016, the Commission set up the High-Level Expert Group on Sustainable Finance (HLEG) and its 2018 report triggered the commitment by the Commission to "accelerat[e] the shift to sustainable finance". On the basis of the HLEG report, the Commission adopted the Action Plan on Financing Sustainable Growth, which aims to: "(1) reorient capital flows towards sustainable investment in order to achieve sustainable and inclusive growth; (2) manage financial risks stemming from climate change, environmental degradation and social issues; [and to] (3) foster transparency and long-termism in financial and economic activity". 6

The goal is not only to make the financial market more sustainable by fostering a long-term view, but also to use it as a driver towards more socially responsible enterprises and to enhance the transition towards a more sustainable growth of the real economy.

On the other hand, the international financial market has seen the steady growth of 'socially responsible investing', better known as 'SRI'. This expression refers to investors that integrate social and environmental considerations

mains the fact that the figures are largely self-reported and Eurosif does not have the capacity to verify all of these figures"; see 2018 Eurosif Report, supra fn. 1, 14.

2 'ESG' stands for Environmental, Social and Corporate Governance. These are now worldwide considered the three central factors in measuring the sustainable and ethical impact of investments.

3 As already noted, sustainable finance is characterised by a serious lack of clarity in terms of definitions. One example is the European Commission webpage dedicated to sustainable finance, which uses the expression 'green finance' interchangeably with 'sustainable finance'; see the section "overview” on https://ec.europa.eu/info/business-economyeuro/banking-and-finance/green-finance_it (last accessed on 9 August 2020).

4 The development of efficient ways to channel private investments to the benefit of sustainable enterprises and projects has been the core subject of the second conference on sustainable finance, 'High-level conference: A global approach to sustainable finance', organised by the European Commission on 21 March 2019.

5 Communication from the Commission to the European Parliament, the European Council, the Council, the European Central Bank, The European Economic and Social Committee and the Committee of the Regions, Action Plan: Financing Sustainable Growth, 8 March 2018 [COM(2018) 97 final].

6 Ibid., at 2. 
into the research, analysis and selection of investments, or which adopt selection criteria that exclude beneficiaries that have a negative or not sufficiently positive impact on the environment or society, together with beneficiaries that are not managed in a sufficiently transparent and participative way. ${ }^{7}$

There are six main SRI strategies for investment selection known in market practices: $^{8}$ (i) sustainability-themed investments (assets specifically related to sustainability funds); (ii) best-in-class investment selection (where investors choose companies with the highest ESG or other criteria-related scores in a specific industry); ${ }^{9}$ (iii) the exclusion of holdings from a specific investment universe (based on the exclusion of specific business sectors such as weapons, or countries that regularly violate human rights); ${ }^{10}$ (iv) norms-based screening (where beneficiaries are selected on the basis of human-rights fulfilment or the adoption of certain guidelines such as the UN Global Compact):;1 (v) ESG factors' integration in financial analysis; and (vi) engagement and voting on sustainability issues.

\subsection{Social Impact Investing}

Social impact investing can be considered as a specific type of the broader category of socially responsible investing, and sometimes it is understood as an SRI investment strategy. ${ }^{12}$

Social impact investing consists of hybrid forms of finance where investors' actions are driven by both economic and social interests. Without a clear legal definition, we can describe it only in terms of market practice, where impact investing is characterised by three main features:

7 See the definition developed by the 2018 Eurosif Report, supra fn. 1, at 12 .

8 Without a legal framework on socially responsible investments, a definition should necessarily be ascribed to market practices.

9 With only minimal differences these criteria are shared by the guidelines developed by Eurosif, the Global Sustainable Investment Alliance (GSIA), and the European Fund and Asset Management Association (EFAMA), as well as the United Nations' Principles for Responsible Investment (PRI).

10 Historically, this is the first, and most widespread, technique of 'ethical' investment. It was adopted in eighteenth-century England, where the members of some religions refused to invest in enterprises based on slave labour.

11 These criteria are common to the guidelines developed by Eurosif, the Global Sustainable Investment Alliance (GSIA), the European Fund and Asset Management Association (EFAMA), and the United Nations' Principles for Responsible Investment (PRI).

12 For instance, impact investing has been considered as a selection criterion by the Eurosif research, see the 2018 Eurosif Report, supra fn. 1. 
1) Intentionality: the purpose of impact investing is to generate a positive and measurable social and/or environmental results;

2) Additionality: this positive impact is pursued together with a 'traditional' financial return;

3) Measurement: social impact investing must "account for in a transparent way on the financial, social and environmental performance of investments", ${ }^{13}$ and the implementation of a monitoring process to quantify the impact generated by the investment activities is required to support the social mission. ${ }^{14}$

Social impact can be obtained by adapting traditional financial tools (e.g. shares, bonds) or by devising new financial instruments (e.g. social impact bonds). In the first case, compared to their traditional correspondents (e.g. conventional bonds or shares in traditional companies, etc.), impact investments are generally 'patient capital': ${ }^{15}$ namely, they do not pursue short-term financial returns. In general, sustainable financing rejects a short-term approach, which is not perceived as shorter-term financing - and indeed "liquidity management, treasury, trade credit and other financing of short duration all have their place in a sustainable financial system" - but as the "practice of finance that is focused on near-term profits rather than strategic fundamentals" and which is "reflected in analysis, allocation and trading that seeks to extract value over a time horizon where the underlying economic returns do not have the time to materialise". ${ }^{16}$

Despite the absence of a European legal framework for impact investing, the European Commission, together with the European Committee of the Regions, has recently highlighted the importance for the European Union of supporting municipal and regional initiatives, such as green bonds, social bonds and sustainable bonds. ${ }^{17}$

This article focuses specifically on social bonds. After a preliminary description of the regulatory framework, it identifies the key legal aspects of these bonds,

132018 Eurosif Report, supra fn. 1, 36.

14 See the opinion of the European Economic and Social Committee on 'Social Impact Investment' (own-initiative opinion), OJ C 458, 19 December 2014.

15 Jacqueline Novogratz, "Making a Case for Patient Capital”, available at https://medium. com/@jnovogratz/making-the-case-for-patient-capital-219305ea9e07 (last accessed on 9 August 2020). See also Sarah Dadush, "Regulating Social Finance: Can Social Stock Exchanges Meet the Challenge?”, University of Pennsylvania Journal of International Law, 2015, 37, 139.

16 High-Level Expert Group on Sustainable Finance, Final Report (2018), 9.

17 See, for example, the opinion of the European Committee of the Regions on 'Action Plan: Financing Sustainable Growth' (2019/C 86/04), para. 22. 
stressing potential weaknesses, and suggesting possible contractual remedies and regulatory interventions to enhance the integrity of the social bond market.

\section{Social Bonds: Towards a Common Definition}

Social bonds are commonly defined as debt securities ${ }^{18}$ where proceeds are used to finance projects or ventures in order to achieve positive social outcomes or to address specific social issues. Social bonds have begun to spread in the wake of the green bonds market ${ }^{19}$ and, together with the latter, they are more a 'market product' ${ }^{20}$ than a regulatory one.

18 In general, a bondholder is entitled to the repayment of the entire loan plus a periodic payment of interest, following the conditions set out in the contract.

19 For an analysis of the green bonds market, see Caroline Flammer, "Corporate Green Bonds", Academy of Management, 2019; and Stephen Kim Park, "Investors as Regulators: Green Bonds and the Governance Challenges of the Sustainable Finance Revolution”, Stanford Journal of International Law, 2018, 54, 1, especially at 14-17. The early development of the market for green bonds rather than the market for social bonds, together with the European Union Commitment to the 2015 Paris Agreement, may be the reasons why EU policy on sustainable finance focuses mainly on the green component of sustainable finance, rather than the social one. See the workplan of the initiatives set out by the European Commission in its 2018 Action Plan, Annex III.

20 The first social bond issuers were public financial institutions with a declared social mandate. Even if not formally qualified as such, the first social bond can be traced back to the 2014 bonds' issue of the Inter-American Development Bank, whose proceeds were used to fund social-project loans eligible under the EYE (Education, Youth, Employment) programme. Similarly, the International Finance Corporation (IFC) launched the Social Bond Program in 2017, issuing social bonds in public and private markets. As of 30 June 2019, the IFC has issued 28 social bonds raising 1.46 billion USD. The IFC social bonds programme has been aligned with the ICMA Social Bond Principles (infra para. 2.).

Later, commercial banks started to issue social bonds. See, for example, the UBI Banca social bond programme (information available at https://www.ubibanca.com/Social_ bond; last accessed on 9 August 2020); or Deutsche Bank, which launched its first social bond in July 2014 in Italy, collecting subscriptions for about Euro 20 million (information available at https://www.db.com/italia/en/content/social-bond-target-achieved. html; last accessed on 9 August 2020).

Finally, corporations began to issue social bonds, as well. For example, Danone, in partnership with Crédit Agricole CIB, issued social bonds in March 2018, aligning them to the ICMA Social Bond Principles (see infra para. 2.) and raising approximately Euro 300 million. The bonds have a 7-year maturity, offer a $1.00 \%$ coupon and are due on March 2025. The bond is listed on Euronext Paris; and is supported by the second-party opinion of Vigeo Eiris. The bond proceeds have been allocated to research and innovation for medical nutrition (36\%), social inclusiveness $(22 \%)$, responsible farming and agriculture $(13 \%)$, entrepreneurship financing $(7 \%)$ and quality healthcare and parental support (1\%); while $21 \%$ of proceeds is not yet allocated at the time of writing. 
Despite the growing market for social bonds and for impact investing in general, there is no public regulatory infrastructure; while in March 2018 the European Commission declared its intention to develop standards for green financial products, ${ }^{21}$ no regulatory plan is addressing social bonds. ${ }^{22}$

Given the absence of a legal framework, a definition for social bonds needs to be found in market practice and private regulation.

The International Capital Market Association (ICMA) ${ }^{23}$ has developed a set of 'Social Bond Principles' (SPBs), meant as a voluntary guidance process for is-

21 Technical Expert Group on Sustainable Finance (TEG), Report on Proposal for an EU Green Bond Standard, 2019: the development of EU green bonds' standards is meant "to enhance the effectiveness, transparency, accountability, comparability and credibility of the green bond market without disrupting the market, and to encourage bond issuers to issue their bonds as 'EU Green Bonds"” (Recommendation No. 1).

Further relevant proposals at the EU level are: Regulation (EU) 2019/2088 of the European Parliament and of the Council of 27 November 2019 on sustainability-related disclosures in the financial services sector; and the Commission Proposal for a Regulation on the establishment of a framework to facilitate sustainable investment (COM (2018) 353 final), including the development of a taxonomy that would enable market actors to know in advance what can be considered a socially responsible investment $[\operatorname{COM}(2018) 353$ final], and that has been approved by the European Parliament and the Council on June 28, 2020: Regulation (EU) 2020/852 of the European Parliament and of the Council of 18 June 2020, on the establishment of a framework to facilitate sustainable investment, and amending Regulation (EU) 2019/2088. A third proposal aims to amend Regulation (EU) 2016/1011 on low carbon benchmarks and positive carbon impact benchmarks. Finally, there is an ongoing debate at the EU level on a planned amendment of MiFID II to include social and/or environmental concerns.

22 The High-Level Expert Group on sustainable finance advises the Commission to begin with the green side of sustainable development, to then move to the social dimensions: "At a later stage, the Commission should also examine the development of a European social label to finance social objectives in a framework to be defined", see HLEG Final Report (2018), at 24. See also HLEG informal supplementary document on sustainable taxonomy (action \#1), at 1 . Nevertheless, the European Commission Action Plan of March 2018 does not include any specific reference to social bonds.

23 The International Capital Market Association is a self-regulatory body, a not-for-profit trade association involving participants in capital markets. It was created in 2005 from the merger of the International Primary Market Association and the International Securities Market Association and now covers both the primary and secondary market. Its objectives are "to promote good relations among its members and to provide a basis for joint examination and discussion of questions relating to the international capital and securities markets and to issue rules and make recommendations governing their operations", and to "provide services and assistance to participants in the international capital and securities markets". As at March 2020, it has over 600 members in 62 countries. More information available at https://www.icmagroup.org/About-ICMA/ (last accessed on 9 August 2020). The prestige and authority of the ICMA guidelines are also testified by the fact that they have been endorsed by leading public issuers, such as the 
suing social bonds, freely available to market participants and designed to increase capital allocation to projects that have a positive social impact. ${ }^{24}$ The guidelines address social bond issuers who are primarily responsible for implementing the Principles, and they are intended for investors to familiarise with the language, institutions and intrinsic structures of social bonds.

The Social Bond Principles define social bonds as any type of bond instrument whose proceeds are exclusively employed to finance (or re-finance in part or in full) ${ }^{25}$ 'eligible' social projects (as listed in the guidelines), and which complies with the four core components of the Principles that define methods and processes for social issuers, as follows:

1) Use of proceeds: proceeds must be employed to finance projects meant to provide specific social benefits or to address specific target populations. The document provides a list of social project categories, including but not limited to affordable basic infrastructure (such as clean drinking water or transport); access to essential services (such as health or education); affordable housing; employment; food security and sustainable food system; socioeconomic empowerment. Target populations include those "living be-

IFC, which has aligned its social bond programmes to the Social Bond Principles; see supra fn. 20.

24 The first set of principles dates back to 2016 and was developed based on the ICMA Green Bonds Principles. Social Bond Principles are now in their fourth edition (June 2020). The Principles are available online, at https://www.icmagroup.org/green-socialand-sustainability-bonds/social-bond-principles-sbp/ (last accessed on 9 August 2020). This is how the Social Bond Principles pose themselves, avoiding any mandatory language and including the following disclaimer: "The Social Bond Principles are voluntary process guidelines that neither constitute an offer to purchase or sell securities nor constitute specific advice of whatever form (tax, legal, environmental, accounting or regulatory) in respect of Social Bonds or any other securities. The Social Bond Principles do not create any rights in, or liability to, any person, public or private. Issuers adopt and implement the Social Bond Principles voluntarily and independently, without reliance on or recourse to the Social Bond Principles and are solely responsible for the decision to issue Social Bonds. Underwriters of Social Bonds are not responsible if issuers do not comply with their commitments to Social Bonds and the use of the resulting net proceeds. If there is a conflict between any applicable laws, statutes and regulations and the guidelines set forth in the Social Bond Principles, the relevant local laws, statutes and regulations shall prevail”.

25 It should be possible for a social bond to re-finance social projects or subjects, as implied by the ICMA guidelines as well; see the ICMA guidelines Introduction: "Social Bonds are any type of bond instrument where the proceeds will be exclusively applied to finance or re-finance in part or in full new and/or existing eligible Social Projects (...) and which are aligned with the four core components of the SBP (...)" [emphasis added]. This practice would enhance the adoption of a long-term view of market actors and it seems consistent with the concept of sustainable finance itself (see supra para. 1.). 
low the poverty line (...), marginalised populations (...), people with disabilities, migrants (...), [the] undereducated (...), [the] underserved (...), [the] unemployed, women and/or sexual and gender minorities, aging population and vulnerable youth, [and] other vulnerable groups $(\ldots)^{\prime \prime} ;{ }^{26}$

2) Project or business evaluation and selection: investors should be informed of the social objectives, the process of project selection and the projects' eligibility criteria;

3) Management of proceeds: proceeds should be tracked and managed in a way that ensures commitment to the social impact;

4) Reporting techniques: the guidelines recommend transparency, disclosure and reporting mechanisms to make social bonds more appealing products in the financial market.

This is the basis of any social bond's issue and must be assessed against the bond's terms and conditions. The details of the ICMA guidelines are examined in the following paragraphs. The analysis of the ICMA definition together with social bond experiences, all help identify the main characteristics of social bonds.

\section{Core Characteristics of Social Bonds}

As long as they seek to generate a positive social impact, social bonds can differ to some degree in the ways proceeds are employed and investment risk is balanced, as well as in relation to the social-impact timeframe or the role of the issuer. What should always be ensured is the generation of a social positive impact through the allocation of (even part of) the proceeds by a sophisticated subject (the issuer) that is in charge of selecting the project or the beneficiary and monitoring the effective generation of the social impact.

Within this frame there are three main distinctions which may facilitate the development of different types of social bonds. Categories of social bonds may mainly depend on:

1) Who is in charge of achieving the social impact (issuer or beneficiary), and on what legal basis;

2) The definition given to the achievement of the 'social' impact;

3) Investor remuneration. 


\subsection{The Issuers of Social Bonds and Their Role in Achieving the Social Impact}

A first distinction can be made depending on who is in charge of producing the social impact: the beneficiaries or the issuer.

Traditionally, social bonds have been issued to finance specific projects, ventures, or categories of ventures addressing targeted social issues. They normally involve three subjects: the issuer (e.g. a corporation, a bank, or other financial institutions), bondholders, and one or more 'beneficiaries' that are funded by the issuer thanks to the capital raised by issuing social bonds. Therefore, the beneficiary or beneficiaries are in charge of generating the social impact as contractually defined (e.g. building the hospital or developing the educational programme). These bond types can in turn be divided into two subtypes, depending on the issuer's way of financing the beneficiary/ies: 'grantbased' and 'loan-based' social bonds. In the so-called 'grant-based' social bonds the issuer assigns a certain amount of money to finance a social project or venture (traditionally a non-profit organisation). By contrast, the so-called 'loan-based' social bonds help raise capital that will be employed by the issuer to grant loans at better-than-market conditions to selected targets of businesses. Loan-based social bonds allow a leverage effect that breaks the dependency of social enterprises on grant funding, making loans to social businesses less expensive. ${ }^{27}$

A second category of social bonds can be identified whenever corporations issue bonds to collect resources to be used to improve their own positive social performance (e.g. to finance a health programme for their employees, or to start an employee's family support programme). In this case, there are only two types of subjects involved (issuers and bondholders), and the issuer itself is responsible for the generation of the social impact.

Those two different types of social bonds may generate different legal issues. For instance, whenever the issuer is in charge on the social impact, it is even more important to provide for investor safeguards in terms of traceability of proceeds (para. 4.1.), and to consider appointing a bondholders' representative (para. 4.3.).

27 These types of social bonds have been issued, for instance, by the Italian bank, UBI Banca. An example of grant-based social bond is their 'UBI Comunità per la Fondazione Umberto Veronesi', while an example of loan-based social bond is the 'UBI Comunità per l'imprenditorialità sociale del sistema CGM'. Information is available at the UBI Banca website (https://www.ubibanca.com/Social_bond; last accessed on 9 August 2020). It is not uncommon for issuers of social bonds to issue both types of social bonds. 


\subsection{The 'Social' Side of Social Bonds: The Lack of a Common Definition of 'Social Impact'}

To be defined as a social bond, a bond has to commit proceeds to generate a 'social impact'. The absence of a clear definition of what is deemed 'social' - or 'green' or 'sustainable' - may hinder the development of a sustainable financial market.

The need to clarify the meaning of 'sustainable' impact has been acknowledged by the European Commission itself in its Action Plan of March 2018. This has also clearly emerged in the Taxonomy Technical Report of June $2019,{ }^{28}$ but only with specific reference to the concept of 'environmental sustainability' and 'green bonds'. By contrast, at the time of writing there is no work in progress on the development of a common definition of positive social impact, with the consequent centrality of the contract in determining the social benefit.

In general terms, three key questions remain unanswered. The first is whether in determining the business' or project's positive social impact it is necessary to look at the impact as a whole, including its environmental effects. The ICMA guidelines state: "It is understood that certain Social Projects may also have environmental co-benefits, and that the classification of a use of proceeds bond as a social bond should be determined by the issuer based on its primary objectives for the underlying projects". However, it goes on to state that "bonds that intentionally mix green and social projects are referred to as Sustainability Bonds". ${ }^{29}$ A reasonable interpretation of such a 'provision' should be that social bonds are created to generate a social positive impact and in doing so they can avoid aiming to generate a positive environmental impact. Yet, this does not mean that social bonds can generate a negative environmental impact. This may not, however, be as simple as it appears since environmental concerns may contrast with social needs, and sometimes a choice has to be made between one interest over another.

28 See the report of the EU Technical Expert Group on Sustainable Finance: TEG, Taxonomy Technical Report, June 2019. The Taxonomy forms part of the implementation of the Action Plan on Sustainable Finance.

The Action Plan contains 10 actions, some of which have led to political agreements. In July 2018, the European Commission set up a technical expert group to assist it in developing an EU classification system - the so-called Taxonomy - to determine whether an economic activity is environmentally sustainable, an EU Green Bond Standard, benchmarks for low-carbon investment strategies, and a guidance to improve corporate disclosures of climate-related information (at 15). Based on the results of the TEG researches, the Commission developed the Proposal for a Regulation on the establishment of a framework to facilitate sustainable investment (COM(2018) 353 final), which has been recently approved by the European Parliament and the Council (June 28, 2020; Regulation (EU) 2020/852) (supra fn. 21).

$29 \operatorname{ICMA}(2020)$. 
A second uncertainty is whether there are any activities that should not be financed through social bonds. For instance, can a bond issued to finance a business that produces weapons, but that employs a high percentage of disabled employees, qualify as a 'social' bond?

A third aspect is the worrying practice of conferring the social qualification to very generic activities, such as financing MSMEs. ${ }^{30}$ Sometimes even 'access to finance' is treated as a social good per se. ${ }^{31}$ In sophisticated markets, however, these practices should not be encouraged by international guidelines such as the Social Bond Principles: the social impact should go beyond the natural positive effects of the financial market itself. A loose definition of social impact may allow the inclusion of many projects and businesses under the social bond umbrella, which could negatively affect the understanding of social bonds, and thus reduce their attractiveness.

However, with regard to the impact 'component' of social bonds, the question of precisely which activities and projects can or cannot be financed does not really have an impact on the legal aspects of this financial instrument. On the contrary, different timeframes of impact achievement create different legal challenges.

In some cases, the social impact is achieved through the 'simple' act of financing the beneficiary: this is the case of loan-based social bonds issued to collect resources to grant loans at below market rates to specific business categories, and which generate a positive social impact by virtue of their mere 'existence' on the market (e.g. businesses owned and managed by minorities): in this case the social impact is achieved when the business receives the loan.

In other cases, impact achievement requires both time and the collaboration of the beneficiary. This is, for instance, the case of social bonds issued to grant resources to build a hospital, or to loan money at favourable rates provided that the beneficiary has a programme of hiring more workers with disabilities every year for the next $x$ years. These social bonds with a long-term impact raise specific challenges in terms of ongoing evaluation of the beneficiary's behaviour, or of the issuer's conduct (whenever the issuer is also the beneficiary, see supra para. 3.1.).

30 This was the case of the social bonds issued by the Spanish Instituto de Credito in January 2015. The 1 billion Euro bond (with a 3-years term) was meant to help financing SMEs in economically depressed areas of Spain, and it excluded businesses considered socially unsustainable. See Ross, Social Bonds, HSBC (4 July 2016), available at https:// www.gbm.hsbc.com/ /media/gbm/reports/insights/social-bonds.pdf (last accessed on 9 August 2020).

31 See Dadush (fn. 15), 167. 


\subsection{Bondholder Remuneration}

When social investors buy social bonds, they expect to contribute to the generation of a social impact and be remunerated for doing so. ${ }^{32}$ However, the absence of a financial remuneration does not seem to overturn the nature of the social bond.

A full allocation of proceeds in favour of the social purpose, without any remuneration for bondholders, actually enhance the social impact of the single bond. However, such bond may realistically attract only 'public-oriented' investors, meant as proper public entities or investors with a declared mission that is purely altruistic. Differently, a private investor may be less attracted by social bonds with no financial remuneration: the same result-sometimes at a lower cost - could be obtained through a direct donation to the social project or venture; here the investor would suffer lower contractual and monitoring costs, and possibly enjoy the tax benefits that may come with grants. Moreover, private institutional investors would be limited by their core mission and could not underwrite social bonds that are not financially remunerated.

On the contrary, private investors could be more attracted by social bonds that provide financial remuneration. Even if these bonds would reduce the money allocated to the social impact for a single bond-due to the resources saved to reward the investor - they can improve the resources of the social bond market overall considered by attracting different types of investor: not only purely altruistic investors, but also investors willing to generate a positive social impact without relinquishing their right to financial remuneration. This would make social bonds attractive to the growing market of 'hybrid' investors that consider non-financial interests driven by financial interests. ${ }^{33}$

In conclusion, social bonds may vary in relation to the existence of a third beneficiary (para. 3.1.), the employment of proceeds or the impact achievements' timeframe (para. 3.2.), and with regard to bondholders' remuneration. Finally, social bonds may differ depending on the investment risk. For example, the social investors' financial remuneration could be partially linked to the

32 The remuneration of a social bond is often imagined as lower than the interest rate of traditional bonds. This may be often the case, since social bonds can be more expensive from the issuer perspective, for example in terms of monitoring costs or reporting $\mathrm{du}-$ ties. However, this may not be the case when the issuer is also the beneficiary, or more in general whenever issuing social bonds can heavily improve the issuer's market reputation, thus 'compensating' for the increase in costs.

33 Institutional investors benefit from SRI investments whenever they allow investors to diversify their portfolios, thus reducing the risk of financial loss. See Richardson (fn. 1), 555. The Eurosif research has showed how institutional investors' consideration for SRI is rapidly growing; see 2018 Eurosif Report, supra fn. 1. 
outcome of the social project-with or without potential recourse to the issuer. ${ }^{34}$ In much the same way, bonds can be issued as collateralised by one or more specific social projects - including covered bonds, asset-backed securities, mortgage-backed security, and so forth. ${ }^{35}$

\section{The Integrity of the Social Bond Market: How to Reduce 'Socialwashing'}

Even if social bonds are among the most recent forms of sustainable financing, they are rapidly spreading throughout financial markets, especially in Europe. ${ }^{36}$ The fact that social bonds - together with green bonds-are flexible, easy to understand, and often resemble traditional bonds makes them attractive to institutional investors and private corporations alike. ${ }^{37}$ However, as part of the impact investing family they are vulnerable to 'socialwashing'. ${ }^{38}$

34 This is what the ICMA guidelines call 'a social project bond'; see ICMA (2020), Appendix I.

35 Secured bonds are also provided by ICMA principles. See ICMA (2020), Appendix I, which also includes so-called 'social revenue bond': "a non-recourse-to-the-issuer debt obligation aligned with the Social Bond Principles in which the credit exposure in the bond is to the pledged cash flows of the revenue streams, fees, taxes etc., and whose use of proceeds go to related or unrelated Social Project(s)".

36 Recent data shows that in 2018 the growth of the social bond market was stronger than the market for green bonds: the international green bond market issues 174.9 billion USD, compared with 173.5 billion USD the previous year $(+0.8 \%)$; while social bonds raised 13.9 billion USD, compared with 11.2 billion USD in $2017(+24.1 \%)$, and less than 3 billion USD in $2016(+363.3 \%)$. Data are taken from Environmental Finance, Sustainable Bonds Insight (2019), available at https://www.environmental-finance. com/ (last accessed on 9 August 2020), which also shows how the European market is the most developed one.

37 See supra fn. 20. See also Brad M. Barber/Adair Morse/Ayako Yasuda, "Impact Investing”, NBER Working Paper No. 26582/2019. In 2018, the largest issuer was BPCE (with social bond issuing of totally 3,465 million USD), while the largest single social bond was the one of the African Development Bank (social bond for a value of Euro 1,250 million). Danone was the largest corporate issuing social bonds (for a total value of Euro 300 million). Info at Environmental Finance, Sustainable Bonds Insight (2019), supra fn. 36.

38 This neologism is inspired by the better-known expression 'greenwashing' or making people "believe that your company is doing more to protect the environment than it really is". The term 'socialwashing' refers to the phenomenon of disinformation spread by an organisation presenting a socially responsible public image which does not correspond to reality. See Stephen Kim Park, "Social Bonds for Sustainable Development: A Human Rights Perspective on Impact Investing”, Business and Human Rights Journal, 2018, 3, 233, at 234; and John Gerard Ruggie, "Multinationals as Global Institution: Power, Authority and Relative Autonomy”, Regulation \& Governance, 2017, 317. 
Social bonds are, de facto, 'standardised' financial instruments, where the actors involved are presumed to (also) act in the interest of generating a positive social impact. Any action that deviates or distorts this interest will damage the integrity of the social bond market, to the detriment of investors who genuinely engage in this market on account of its social impact.

Market actors should not be allowed to conceal traditional financial tools behind the 'social' (or 'green') label, making them more attractive on the market, for two main reasons:

1) To safeguard bondholders who underwrite a social bond on account of the agreement that bond proceeds will be allocated to generate a social impact: if the investment rationale is the social impact, stakeholder interest becomes part of the contract, a 'condition' for investors to finance; they are no longer third-party interests, but an integral part of the bondholder's interest;

2) To preserve the integrity of the social bond market: the natural dynamic of such bonds (bondholders invest on the basis of a specific interest that bond proceeds are allocated to a social project or third party that generates a social impact) comes with several potential conflicts of interest. These are higher than those of traditional bonds since there are three parties involved (bondholders, issuers and beneficiaries) and interests which are heterogeneous (financial and non-financial interests). Also, social bonds drive up agency costs, and contractual costs increase due to any higher costs related to the analysis of these financial tools compared to traditional bonds. It is thus vital to prevent the actors that issue social bonds in good faith - having to bear additional costs compared to traditional bondsfrom suffering from the deteriorating reputation of these financial instruments. ${ }^{39}$

The approach adopted with social bonds differs from the ESG proposal. The ESG approach is designed to increase the duties of compliance with environmental and social standards of investors and market actors, based on the political view that a transition to a more sustainable financial market (and then to a more sustainable real economy) is necessary, as well as on the basis that adopting a long-term view can be profitable. When it comes to social bonds, however, the goal is just to ensure that enterprises do what they say they are doing

39 This is consistent with the EU framework for fair competition, which is designed to ensure fair and equal conditions for enterprises, "while leaving space for innovation, unified standards, and the development of small businesses"; European Union webpage on competition, at https://europa.eu/european-union/topics/competition_en (last accessed 9 August 2020). 
in terms of sustainability, so as to avoid socialwashing and to preserve the integrity of financial markets for social bonds.

In line with these goals, the considerations developed below are designed to foster the analysis of the legal implications and, more broadly, the debate on these new financial tools.

There are two main types of risks that the contract or law regulating the issue of social bonds should try to minimise. First, the bondholder's risk that the issuer diverts proceeds to other activities or subjects, thus not fulfilling its social impact obligation. Second, whenever the social impact is not generated by the investment per se, but requires the collaboration of the beneficiary, there is the additional risk of proceeds being diverted for both bondholder and issuer. These risks call especially for the development of disclosure procedures. The second risk requires mechanisms to monitor the beneficiaries. Both involve processes for proceeds' traceability, but also infra-group financing, and require the development of effective enforcement mechanisms. Moreover, within each risk category the approach should vary depending on the planned timeframe for impact achievement (see supra para. 3.2.).

What follows reflects on mechanisms to lock-in proceeds in favour of the generation of a social impact, processes for information disclosure, monitoring tools and procedures relating to both issuer and beneficiary (when the beneficiary is not the issuer), the effectiveness of enforcement mechanisms in case of non-fulfilment, and the role of independent review providers.

\subsection{Allocating Proceeds for the Social Impact}

A core concern is to ensure the commitment of proceeds in favour of beneficiaries as identified in the contract, and to avoid the management of proceeds in a way that is inconsistent with what has been agreed.

Firstly, procedures need to be in place to ensure traceability of proceeds. Crediting the net proceeds of social bonds (or an equal amount) to a sub-portfolio-as suggested by the ICMA guidelines $-{ }^{40}$ could be considered a good rule to fol-

40 Such an apparatus has been established by the IFC, as well. See IFC, Social Bond Impact Report (2018): “Net proceeds from IFC's social bonds are allocated to a sub-portfolio that is linked to lending operations for social bond eligible projects. Only the loan portions of projects are eligible for funding via Social Bond proceeds - equity investments and guarantees are ineligible. (...) In addition to meeting social bond eligibility criteria, all projects financed undergo a rigorous due diligence process. Eligible projects comply with IFC Performance Standards on Environmental and Social Sustainability and the IFC Corporate Governance Framework. Projects are subject to ongoing monitoring 
low. Bondholders should be consequently informed: the issuer should disclose their intended management of proceeds to investors. This should clarify the investment operations engaged to realise the social impact, especially when the beneficiary is identified in a generic way (infra para. 4.2.1.). Ensuring the proper traceability of bond proceeds is even more important when the issuer is the party in charge of generating the social impact, e.g. bonds issued to improve the positive social externalities of the corporate issuer in terms of employee training.

Information should be updated periodically and communicated on a regular basis (e.g. annually). This mechanism should be backed up by the appointment of an auditor, entrusted to verify the internal tracking method and the general allocation of social bond proceeds (see infra para. 5.).

Secondly, the contract should disclose the existence of any economic relationship between the issuer and the beneficiary whenever the beneficiary is a different entity (e.g. being part of the same corporate group). What must be avoided is that the issuer uses social bonds to raise capital that will be employed to finance beneficiaries selected on the basis of the economic return that they will provide to the issuer; a typical example is the circumstance where the beneficiary is a member of the corporate group or an economic partner of the issuer. Any kind of pre-existing and new economic relationships between the issuer and the beneficiary should then be disclosed to bondholders at the time of the underwriting and in periodical reports.

\subsection{Bondholder Ability to Monitor the Generation of the Social Impact}

\subsubsection{The Importance of Clearly Identifying the Social Impact}

In the absence of a precise legal definition of what constitutes 'social', to help bondholders monitor the generation of the beneficiary, social impact should be determined in the bond's legal documentation in the clearest way possible. That is, issuers should specify the beneficiary by indicating the project's and enterprise's category, the industry, and-whenever possible-the alignment with market-wide guidelines: any information that can help the investors in their decision-making process is relevant. In addition, the issuer should clarify what this social impact consists of, also by identifying any target population(s), and the key performance indicators that will be employed to measure the social

and supervision. (...) All proceeds from IFC's social bonds are set aside in a designated Social Cash Account and are invested in accordance with IFC's conservative liquidity policy, until disbursement to Eligible Projects”, at 18; available at https://www.ifc. org/wps/wcm/connect/publications_ext_content/ifc_external_publication_site/publica tions_listing_page/sbim-fy18 (last accessed 9 August 2020). 
outcomes. In this context, the ICMA list of indicative project categorieswhich captures the most commonly used types of projects supported by, or potentially supported by, the social bond market-does not help significantly due to the rather general nature of some of the categories. ${ }^{41}$

Whenever social impact is generated by beneficiaries who are identified by the issuer, the issuer's reputation and future capacity to attract new capital are conditional on the integrity of beneficiaries and their ability to generate the social impact. Thus, even from the issuer's perspective, it is crucial that the legal documentation clearly identifies and assesses how social impact is actualised by the company financed or the project invested in. ${ }^{42}$ This information should also be clearly communicated to bondholders.

Furthermore, where feasible, a quantification of social impact could increase bond appeal, but it should not be considered a core feature. What should be clearly quantified is the amount of proceeds addressed to the beneficiary or funded project, and the bondholder's remuneration on investment. Similarly, the beneficiary should be identified in the most detailed way possible. However, financing the beneficiary could be considered as generating a social impact per se (e.g. financing a medical research centre for innovative oncological treatment) and the absence of an impact quantification in these cases does not seem to diminish the bond effectiveness.

\subsubsection{Ex Ante and On-Going Disclosure of Information}

A clearer identification of social impact in the bond indenture can simplify the monitoring process. Yet the contractual asymmetry of the parties involved and the heterogeneity of the interests tend to undermine monitoring strength and make it ineffective.

To empower investors and to make the monitoring process possible, the issuer should communicate transparent, accurate, and complete information to bondholders in a simple and regular way. ${ }^{43}$ Disclosure of information is the prereq-

41 See supra para. 2.

42 A comparable need has been highlighted by 'green' investors in US companies, who stress the importance of aligning the Climate Lobbying with the Paris Agreement; see Barbara Grady, "A Call by Investors on US Companies to Align Climate Lobbying with Paris Agreement”, posted on the Harvard Law School Forum on Corporate Governance and Financial Regulation, on 1 October 2019, available at https://corpgov.law. harvard.edu/2019/10/01/a-call-by-investors-on-us-companies-to-align-climatelobbying-with-paris-agreement/ (last accessed on 9 August 2020).

43 ICMA (2020), para. 4. Whenever the issuer can be defined as an investment firm under Directive MiFID II (i.e. Art. 4), flows of information must also respect Art. 24 (General principles and information to clients) and Art. 25 on the suitability and appropriateness 
uisite of any monitoring activity, so that transparency and disclosure become crucial to ensure the market integrity of social bonds as well as to enable a comparison with different financial products, thus creating a level playing field for social bonds. ${ }^{44}$

In some cases, where consistent with the national legal framework, administrative rights may also be established to improve monitoring. Bondholders traditionally have no power to influence companies' management; they do not normally have voting rights or other governance rights, unlike equity owners. However, we can imagine mechanisms to increase investors' powers, at least in terms of monitoring. In Italy, for instance, bondholders of public companies (società per azioni) are organised in special assemblies, ${ }^{45}$ one for each bond issue, ${ }^{46}$ that appoint a common representative. The representative has the right to take part in shareholders' general meetings and is in charge of safeguarding the bondholder's interest in their relationships with the company. ${ }^{47}$ Furthermore, the bondholders' meeting is called to approve the modifications to lending conditions. In such legal framework, in the case of a social bond issuing, bondholders could appoint a common representative authorised to take part in any shareholder general meetings, with the consequent ability to access direct information and better monitor the enterprise's behaviour with regard to achieving social impact. However, under the Italian law these governance rights are only for bondholders of public companies, and do not legally apply to bonds issued by banks, ${ }^{48}$ so that governance rights of this kind, in Italy, may not apply to those long-term loan-based social bonds mainly issued by banks for

of reporting to clients. See Directive (EU) 2014/65 of the European Parliament and of the Council of 15 May 2014 on markets in financial instruments and amending Directive (EC) 2002/92 and Directive (EU) 2011/61 (referred to as MiFID II).

44 In terms of disclosure, what needs to be analysed more closely is what happens when the amount of detailed information that can be made available is limited due to confidentiality agreements or competitive considerations. In this case, the Social Bond Principles recommend that information be presented in generic terms or on an aggregated portfolio basis (e.g. percentage allocated to certain project categories). The issue is worth of further analysis.

45 Art. 2415, Italian Civil Code. Bondholders meetings deliberate as per Art. 2365, Italian Civil Code.

46 The common interest of bondholders exists in relation to any single issue and does not identify with the generic quality of bondholder. See the Corte di Cassazione (Supreme Court of Cassation), 31 March 2006, n. 7693, Il Foro Italiano, 2007, 207.

47 Arts. 2417 and 2418, Italian Civil Code.

48 Art. 12 TUB (Legislative Decree, 1 September 1993, n. 385) expressly derogates to Art. 2415, Italian Civil Code; see Danilo Galletti, “"Elasticità' della fattispecie obbligazionaria: profili tipologici delle nuove obbligazioni bancarie”, Banca, borsa, titoli di credito, 1997, 239. For a comment on Art. 12 TUB see also Gian Franco Campobasso. “L'emissione di obbligazioni bancarie”, Banca, borsa, titoli di credito, 1994, 472. 
which monitoring social impact is particularly complicated, and where a bondholders' representative could be important for reducing the deficit of information. Nothing, however, seems to prohibit a contractual provision designed to establish and regulate bondholders' governance rights.

Finally, disclosure should not only concern the issuer's use of proceeds, but also the beneficiary's governance and activity, and the progress made in social impact achievement.

The inability of beneficiaries to address (or mitigate) deviation from the specific social issue and/or to achieve the social outcomes as set out in the contract can damage the issuer. Consequently, from the issuers' perspective, a key concern is the existence and content of engagement policies to oversee the beneficiary's behaviour and social impact achievement. The issuer should demand that the beneficiary provide transparent reporting on relevant sustainability issues in relation to business strategy, operations and risks, including the most significant parts of their supply chain. The assessment should take into consideration the intrinsic long-term view of any social impact, and beneficiaries may also be required to engage with their stakeholders..$^{49}$ In this context, the use of qualitative and, where feasible, quantitative performance indicators is appropriate.

The quality and credibility of non-financial disclosure, however, "is often doubted due to the control that companies exercise over this information". ${ }^{50}$ To prevent socialwashing a third independent party could be selected and be actively encouraged to take responsibility for verifying information (even by means of certification and independent auditing), ${ }^{51}$ and for helping with an informed selection of beneficiaries. ${ }^{52}$ While the issuer could look at the market to appoint an independent auditor, purely private certifications - especially when there is no post-issuing control over the issuer (as it is with the ICMA Social Bond Principles) - risk being less effective ${ }^{53}$. On the opportunity to develop a certification system at the European Union level see infra para. 6.

49 This is Park's line of reasoning, with specific reference to human rights protection, Park, BHRJ 2018, 3 (fn. 38), 245-246.

50 Park, BHRJ 2018, 3 (fn. 38), 247. See also S. Prakash Sethi/Terrence F. Martell/Mert Yasin Demir, "Enhancing the Role and Effectiveness of Corporate Social Responsibility (CSR) Reports: The Missing Element of Content Verification and Integrity Assurance”, Journal of Business Ethics, 2017, 144(1), 59, at 61.

51 Sandra Waddock, "Building a New Institutional Infrastructure for Corporate Responsibility", Academy of Management Perspectives, 22, 2008, 87, at 97-99.

52 Finally, issuers should be encouraged to include the monitoring strategy and achievements in their reporting to bondholders. See ICMA (2020): "Issuers with the ability to monitor achieved impacts are encouraged to include those in their regular reporting”, at 5.

53 For example, green bonds can obtain and maintain the 'label' of 'Certified Climate Bond' if they comply with both pre-issuance requirements set by the 'Climate Bond 


\subsection{Making Monitoring and Enforcement Effective}

If tracking methods for proceeds (para. 4.1.), together with the identification of a beneficiary that is not too generic (para. 4.2.1.), and an adequate disclosure procedure (para. 4.2.2.) could make social bonds more appealing in theory, it is still doubtful whether non-fulfilment by issuers are enforceable in practice. This is because it is required to verify whether, on the one hand, bondholders have the incentives to monitor the issuer; and, on the other hand, whether bondholders have the incentives and capacity to take actions in cases of nonfulfilment. Disclosure is extremely important but may prove useless if the addressee does not have the incentive and strength to correctly monitor and force the issuer to comply with the obligations set out in the bond contract.

Generally, bondholders are believed to have few or no interests in the decisionmaking process of corporate management, since they enjoy priority over shareholders in cases of insolvency. For traditional bonds, creditors' interest consists of being paid back and having their investment financially rewarded. This sort of interest is indirectly satisfied by shareholders' interest in making profits and shareholders are the most motivated when it comes to monitoring management behaviour: as long as the company is solvent, the interests of shareholders and creditors can be considered aligned. On the contrary, shareholders will not necessarily be interested in monitoring the achievement of social impact in cases of issuing social bonds.

Another issue emerges when considering how, in contrast to common bonds, the holder of a social bond is no longer the principal beneficiary of the contract, but the contracting parties (bondholder and issuer) voluntarily decide to benefit a third party. In the worst-case scenario both bondholder and issuer could deviate from the social 'goal' and agree (even implicitly) on a different use of proceeds. If put into practice this approach would undermine the credibility of the financial instrument on the market and cause significant distortion of competition with other social bond issuers. To prevent such deviations, and to make monitoring effective, several contractual devices can be used.

We have already examined the case of appointing a common representative of bondholders - with the example of the Italian 'rappresentante degli obbligazionisti' (para. 4.2.2.) - who could also be empowered to claim for damages in the name of bondholders.

Standards' (Section A), and post-issuance requirements (Climate Bond Standards, at Section B). In addition, these Standards require the issuer to publish periodical reports, which are subject to review by the Climate Bond Initiative. If social bonds do not comply with the post-issuance requirements, the certification is revoked, and this is accordingly publicised. Such a system, for what it is concerned, does not exist for social bonds. 
In this context, and still thinking in terms of contractual solutions, the bond indenture could also establish economic incentives for an external actor to monitor the issuer. The contract could, for instance, identify a second potential beneficiary entitled to claim for social bond proceeds in the case of the issuer's non-fulfilment, thus compensating for the inactivity of the original beneficiary and providing for the cases of undetermined beneficiaries or categories of beneficiaries which are excessively generic. ${ }^{54}$

Another contractual remedy could be the ex-ante identification of a bondholders' trustee responsible for monitoring the issuer's behaviour in terms of social impact achievement and for reporting to bondholders on their findings, and who could be authorised to enforce the breach of contract in the name of the bondholder. ${ }^{55}$

The contract can also provide covenants that restrict the issuer's right to take decisions, by providing penalties for specific behaviours.

\subsection{Consequences of Non-Fulfilment of the 'Social' Obligation}

From the investor's perspective, if the issuer does not comply with the repayment obligation, traditional enforcement tools apply, and the bondholder could potentially claim for an order of compliance and legal compensation. Differently, there is much less certainty when it comes to the consequences faced by the issuer in cases of failure to comply with its duty to use proceeds to finance social projects or ventures. This sort of situation would seem to integrate a breach of contract, as in the case of non-compliance with repayment obligations: when the bondholder chooses a social bond because of its 'social' nature, this choice integrates a legal interest worthy of protection within the legal framework of the European Union. Nevertheless, social bonds are not only an expression of freedom of contract, but are also consistent with the European political choice to engage private finance in the process of supporting the transformation of Europe's economy into a more sus-

54 This dynamic can be found in inheritance law. A good example is the will of Isabella Stewart Gardner, the founder of the Isabella Stewart-Gardner Museum in Boston (USA), which states that in the event of significant changes to the art collection, the museum must be sold, and the money donated to Harvard University. The will contractually creates economic incentives to Harvard University, which is now interested in monitoring the museum's management. For more detailed information see https://it. scribd.com/doc/80254471/Isabella-Stewart-Gardner-s-Will (last accessed on 9 August 2020).

55 Depending on national laws, the trustee is subject to general fiduciary duties, such as the duty of loyalty and the duty to avoid conflicts of interests. 
tainable one. ${ }^{56}$ The development and dissemination of a new financial instrument go hand in hand with the protection provided by law in cases of nonfulfilment.

To facilitate the recognition of such a legal interest, international guidelines such as the ICMA Principles-together with any future regulation-should suggest that, in bond indentures, the rationale behind the underwriting and the bondholder's willingness to generate a (more or less) specific social impact through the allocation of bond proceeds be made explicit. However, this leaves room for several and still unanswered questions.

Firstly, what happens in the case of non-performance of the social impact obligation when this requires the collaboration of the beneficiary? There appear to be three main options open:

1) The issuer is the only person accountable to the bondholder in the case of non-fulfilment;

2) The issuer and the beneficiary are jointly liable;

3) Issuer accountability can be negotiated, and can be excluded by contract, leaving the beneficiary as the sole party liable.

The last option, if legally feasible under national law, ${ }^{57}$ should be discouraged. The issuer is the one primarily responsible for the generation of social impact not only because it is the issuer who selects and negotiates with the beneficiary, but also because, from an efficiency perspective, the issuer will probably be a more sophisticated actor than the bondholder, and in a better position to monitor the behaviour of the parties involved. Removing the issuer's potential liability will eliminate any incentive for the issuer to monitor the beneficiary's effective engagement to generate a positive social impact and, more generally, to cooperate in order to give full effect to the contract.

56 Principle firmly stated by the European Commission 2018 Action Plan. See also supra para. 1.1.

57 With the exception of specific types of contract, general contract law is not dealt with under European law, and the contractual consequences of non-compliance are regulated by Member States' legal systems. However, whenever the social-bondholder falls within the definition of 'consumer' under Directive (EC) 1993/13 (see Art. 2(b)), a contract provision excluding issuer liability could be considered unfair, in the sense that the clause has not been individually negotiated and that, "contrary to the requirement of good faith, causes a significant imbalance in the parties' rights and obligations arising under the contract" (Art. 3(1)). If so, the clause should "not be binding on the consumer" and "the contract shall continue to bind the parties upon those terms if it is capable of continuing in existence without the unfair terms" (Art. 6). 
On the other hand, the first two options both seem feasible, and a joint liability of issuers and beneficiaries is probablies the preferred solution from the bondholder's perspective.

Secondly, for any social bond it is doubtful whether the bondholder can claim specific performance of the contract (at least in those legal systems where national law regulates the right to performance of non-monetary obligations) when the beneficiary is not identified by the contract, or he/she can only claim for damages. This is why the terms and conditions of the bond should both be as specific as possible-if not in the details of the project or company to be financed, at least -in the process and criteria adopted to evaluate and select the beneficiary project or enterprise (supra para. 4.2.1.), and regulate the case of non-performance.

Thirdly, it is not clear how damage is to be quantified. One partial solution would be to use contractual covenants in bond contracts that provide for acceleration in terms of non-compliance. ${ }^{58}$

Finally, there is clear room for public supervision, albeit what its structure and extent should be requires further reflections. In particular, it is conceivable that the violation of the duty to generate social impact be considered as a market manipulation under Article 12, Regulation (EU) No. 596/2014 ('MAR') and Article 5, Directive (EU) 2014/57 ('MAD II'). ${ }^{59}$ In this perspective, it seems important to distinguish the case in which the failure to comply with the 'social impact' obligation was already existing at the moment of the issuing (e.g. social bonds issued with no intention nor capability to generate a positive social impact), from the case in which the impact was never realised despite the issuer's will (e.g. the beneficiary did not build the hospital as it was supposed to do).

Moreover, whenever the issuer of social bonds is subject to Directive (EU) 2014/65 ('MiFID II'), so-called 'product governance' rules can apply, and social bonds can be subjected to the supervision of the European Securities and Market Authorities.

58 Covenants are also suggested by Park, BHRJ 2018, 3 (fn. 38), 252. On the contrary, they are not mentioned by the ICMA Social Bond Principles.

59 On the complex regime of criminal penalties and administrative sanctions for market abuse, see between the many Andrea Perrone, "EU Market Abuse Regulation: The Puzzle of Enforcement”, European Business Organization Law Review, 2020, 1, 379. 


\section{Review Provider}

ICMA guidelines advise the appointment of "external review providers to confirm the alignment of their bonds with the four components of the SBP (...)", and also recommend public disclosure of external reviews.

Some of the risks analysed above could indeed be mitigated through the appointment of a review provider, who could be responsible for:

1) Formulating a second-party opinion on social bond feasibility that will support the issuer in selecting the beneficiary. In this context, the advice of an independent reviewer may help in the identification of social projects or ventures; $; 0$

2) Verifying the tracking method and the general allocation of social bond proceeds;

3) Monitoring the social impact and evaluating its achievement: in contrast to other forms of sustainable finance, an external independent evaluator is not necessary for social bonds. ${ }^{61}$ However, the contract may provide for the appointment of an evaluator, which seems particularly appropriate in the case of social bonds with a long-term impact;

4) Verifying the information released by the issuer to the market.

If appointed, the review provider should be independent of both issuer and beneficiary, at least when he/she is entrusted with the opinion on the social bond feasibility and the verification of the information released by the issuer to the market. On the contrary, and when compatible with national jurisdictions, responsibility for tracking proceeds and monitoring social impact could be conferred to issuers' internal auditors or internal committees, thus limiting the costs.

\section{Final Remarks. A Goal-Oriented 'Label' for Social Bonds?}

Social bonds are a good example of what financial innovation can achieve. At the $\mathrm{EU}^{62}$ and the international level there is a growing awareness of the central

60 ICMA (2020).

61 For social impact bonds (SIBs), for instance, an independent valuator has to be appointed to verify and measure the social impact. On SIBs, see Deborah Burand, "Globalizing Social Finance: How Social Impact Bonds and Social Impact Performance Guarantees Can Scale Development”, New York University Journal of Law and Business, 2013, 9, 447.

62 Europe is still the most developed market for sustainable finance: see Environmental Finance, "Sustainable Bonds Insight" (2019), supra fn. 36. 
role that the private sector can play in supporting sustainable development. In this sense the financial market is essential in providing incentives for activities in line with the goals of the United Nations 2030 Agenda. ${ }^{63}$

In this context, social bonds may be particularly appealing to market actors since they strongly resemble traditional bonds. Yet the social allocation of proceeds generates new challenges. Above we have identified the key components of social bonds and suggested contractual devices to enhance their sustainability, by ensuring the effectiveness of the social impact achievement. However, purely contractual solutions may not be enough to preserve the integrity of the social bond market and to avoid sacrificing those investors who genuinely engage in order to generate a social positive impact, potentially suffering reduced profitability comparing to traditional investments.

To fight socialwashing, the need for some sort of public supervision arises and a 'rulemaking' intervention is called for.

The rationale underlying any regulation of the social bond market should partially differ from what is taking place at the EU level with the awarenessraising process on the so-called 'ESG' ${ }^{64}$ Taken together, all these aim to encourage the financial system to adopt higher standards in terms of environmental and social positive externalities of investment. However, social bonds reach beyond socially responsible investing, since the holders of social bonds do not simply consider environmental and social concerns in their investment selection process (e.g. preferring investments that reduce negative externalities), but want to actively generate a positive social impact. ${ }^{65}$ Consequently, the main issue with impact investing is finding ways to empower these investors driven by the desire for social (or environmental) impact to use the market as a way to achieve it. ${ }^{66}$ By recognising this different 'rationality ${ }^{667}$ that can drive investors in their market choices, it is necessary to adjust the system so as to ensure suitable safeguards. This should be the rationale of a regulatory intervention in this context: not only should the specific bondholder inter-

63 See TEG (2019), supra fn. 28, at 10. Through financing and through the stewardship of investments, investors will influence the decisions taken by corporations and other entities. The European Commission has already stressed how the Union's policy framework is linked to the SDGs of the 2030 Agenda (see Communication of 22 November 2016 on the next steps for a sustainable future); and the Council of the European Union has confirmed the EU and Member States commitment to the implementation of the 2030 Agenda in its conclusions of 20 June 2017.

64 On 'ESG' see also supra para. 1.1. and fn. 2.

65 On the definition of socially responsible investing and impact investing see supra para. 1.

66 This is also stressed by Monitor Institute, "Investing for Social and Environmental Impact: A Design for Catalyzing an Emerging Industry”, January 2009, at 37.

67 See Amartya Sen, “On Ethics and Economics”, $1^{\text {st }}$ ed., 1987. 
est(s) be taken into consideration, but also the general 'SRI market' interest ${ }^{68}$ of preserving social bond integrity in the financial market, thus limiting socialwashing.

In terms of how to regulate, it is believed that many of the solutions described above could be introduced by private ordering and supported by private guidelines, through a 'permissive', rather than 'prescriptive', rulemaking approach. ${ }^{69}$ However, clarifying what 'social impact' means - in line with the 'regulation' of standards for green bonds ${ }^{70}$-appears to be important: ${ }^{71}$ specifying what can be considered a social bond may help reduce uncertainty and avoid the development of socialwashing that will consequently generate scepticism regarding these financial instruments.

Turning to the question of how far a regulatory intervention should go in standardising the content of the contract, a social bond definition should not be too detailed. On the other hand, detail appears to be preferable to a minimal intervention, thus avoiding the risk of adopting a definition that will rapidly become obsolete: a 'goal-oriented' definition could identify a minimum common core of requirements necessary for a social bond to be defined as such, and then be assisted by a set of guidelines for voluntary adoption, which should be devised to take best market practices into account, and their development over time (e.g. imagining a periodic review process of standards).

The need to ensure the trust of investors and civil society in the social impact achievements of social bonds should be weighed against the need to allow so-

68 As already stressed: “Transforming growing investor interest in social finance into considerable capital allocation will necessitate systemic changes to the current system. This includes not only improving products to meet investor goals and performance expectations, but also strengthening the enabling ecosystem, including the infrastructure, skills, and incentives that shape business decisions and are needed to execute transactions. This requires a collective effort by the investor community to overcome key challenges and dismantle barriers to entry for mainstream investors in social finance"; Jessica Davis Pluess/Smruti Govan/Paula Pelaez, "Conditions for Scaling Investment in Social Finance”, BSR Report, 2015, 5.

69 Park, SJIL 2018, 54 (fn. 19), especially 17-22, with regard to the ICMA Green Bonds Principles.

70 A similar debate is ongoing in relation to the EU Ecolabel: after the HLEG suggestion, whether and how to extend the EU label to financial products is currently being discussed. See TEG (2019), supra fn. 28; and EU Commission Proposal for a Regulation of the European Parliament and of the Council on the establishment of a framework to facilitate sustainable investment [COM(2018) 353 final], supra fn. 21.

71 See the opinion of the European Committee of the Regions on 'Action Plan: Financing Sustainable Growth' (2019/C 86/04), para. 31. 
cial bonds to evolve over time and to be responsive to changing market needs. ${ }^{72}$

Consequently, a public regulatory intervention should be made alongside private guidelines. Guidelines for voluntary adoption can be considered a positive tool in promoting integrity, ensuring greater transparency and better enforcement, consequently increasing capital allocation to social bonds. Furthermore, guidelines may allow access to innovative financing not only to banks, professional investors and large corporations, but also to small and medium-sized closed corporations, for which innovation is often too costly. At this preliminary stage, the ICMA guidelines can be considered a good example in terms of intention and methodology, since they are designed to create a collaborative and consultative community. However, they still seem to lack clarity and effective monitoring and enforcement mechanisms, leaving room for improvement.

A combination of improved feasibility and standardisation could enhance the development of a sustainable market for corporate social bonds. Standardisation $^{73}$ in general makes financial instruments less expensive, accessible to unsophisticated investors, and more attractive to market actors. In doing so any (public and private) regulatory regimes must be configured in a way that considers long-term expectations of financial returns. ${ }^{74}$

Finally, what level of regulation has to be reached to arrive at a shared consensus on the notion of social bonds -international, European, national? Ideally, an internationally agreed definition would be the best option. However, there is even less international consensus on what is considered to have a social impact than on what is environmentally sustainable. Social sustainability is highly influenced by a country's standard of human rights' compliance, and international standards on human rights are often weaker than already protected

72 See also Park, BHRJ 2018, 3 (fn. 38), 244: “Governments struggle to regulate many environmental and social impacts attributable to global commercial activity, including impacts that directly implicate human rights. (...) private governance regimes are composed of groups of firms that agree to regulate themselves. Instead of centralized law making and enforcement, private governance generally relies on decentralized processes based on negotiation and dialogue to create standards, which are enforced through investigation and disclosure. Market-based mechanisms assess, measure, audit, label and otherwise facilitate communication of the social and environmental conduct of companies".

73 Standardisation is especially important with regard to non-financial intrinsic structures and measurement across investment activities. To enhance the development of a social bond market it is necessary to develop and standardise non-financial performance indicators, capable of integrating social (and environmental) impact into the valuation and pricing of risk. This is one of the recommendations made to create conditions for scaling investment in social finance; see Davis Pluess/Govan/Pelaez (fn. 68), especially 36-39.

74 This aspect is emphasised by Dadush (fn. 15), 225. 
rights, for instance, those protected by the European Convention on Human Rights, or at the national level in some countries (e.g. US laws against gender discrimination). Working for an international consensus on a common definition of the social impact may therefore lower the level of compliance for some Western or, at least, some European countries.

On the other hand, opting for a national regime, even if it allows a greater level of depth and detail, runs a risk of fragmentation and may enhance competition among legal systems, which may in turn lead to 'a race to the bottom'.

Having considered all this, one valid option may be to look at the EU level for consensus. First, the European Commission has demonstrated a strong political interest on financial innovation. Second, it is building expertise in the sector thanks to its work on the taxonomy for green financial products. ${ }^{75}$ Third, the European Union could easily offer assistance in terms of external control and public supervision of the issuer's compliance with social bond standards: this is vital when it comes to ensuring that what a business declares it is doing is what it is actually doing. The European Union has already shown itself capable of managing such a system. ${ }^{76}$

A European standard, however, should not be limited to European issuing, but should be accessible for potential non-European issuers, in line with the mission of the EU Technical Expert Group on Sustainable Finance for green bonds. $^{77}$

In conclusion, considering the ongoing work at the European Union level in terms of social innovation and sustainable finance, it would be a lost opportunity were the EU's interest in sustainable finance to be limited to green financial products, leaving social bonds out of the debate. In the same way, it seems necessary to clarify the relationship between social impacts and environmental impacts.

75 Proposal for a Regulation on the establishment of a framework to facilitate sustainable investment (COM(2018) 353 final), which includes the development of a taxonomy that would enable market actors to know in advance what can be considered a 'socially responsible investment'. See Regulation (EU) 2020/852, supra fn. 21.

76 The European Union has a high level of expertise in managing labelling systems in general. See, inter alia the EU Ecolabel, and the CE marking for products to be sold in the European Union, but also the energy label, labelling for chemicals, and fish and food labelling.

77 See also supra fn. 28. 
